\title{
Epidermal growth factor receptor immunohistochemistry in different histological types of infiltrating breast carcinoma
}

\author{
M Martinazzi, F Crivelli, C Zampatti, S Martinazzi
}

\begin{abstract}
Aims-To determine the immunohistochemical expression of epidermal growth factor receptor (EGF-R) in high grade, intermediate, and low grade tumours. Methods-Specimens from 931 breast carcinomas were partly formalin fixed and paraffin wax embedded, to classify cases, and partly frozen in liquid nitrogen, cryostat sectioned, and immunostained using two monoclonal antibodies from clone 455 and 528 to demonstrate EGF-R positive cells. An avidin-biotin complex and peroxidase method was used after incubation with biotinylated anti-mouse antibody; colour was developed using a diaiminobenzidine solution. Results-Low grade carcinomas seldom expressed EGF-R $(n=3)$ compared with 106 high grade infiltrating ductal carcinomas: EGF-R positive cases were much less common in infiltrating lobular than in infiltrating ductal carcinoma. Medullary carcinomas did not differ from infiltrating ductal carcinomas.

Conclusions-The very low incidence of EGF-R positive cases in the "special type" group of breast carcinomas with a good prognosis is in line with the absence of the homologous c-erbB-2 and p53 oncoproteins, and the rarity of highly proliferating and oestrogen/progesterone negative cases. EGF-R expression in infiltrating lobular carcinoma was in keeping with the intermediate behaviour of this kind of tumour. EGF-R expression in cases of pure medullary carcinoma is the same as that of high grade tumours.
\end{abstract}

$(f$ Clin Pathol 1993;46:1009-1110)

Epidermal growth factor receptor (EGF-R) is a 170 kilodalton glycoprotein with an extracellular domain binding to the mitogen epidermal growth factor (EGF); it has a transmembrane intracellular domain showing

Table 1 EGF-R expression in intermediate grade breast carcinomas

\begin{tabular}{|c|c|c|c|}
\hline & $\begin{array}{l}\text { Infiltrating lobular } \\
\text { carcinoma }\end{array}$ & $\begin{array}{l}\text { Pure medullary } \\
\text { carcinoma }\end{array}$ & $\begin{array}{l}\text { Infiltrating ductal } \\
\text { carcinoma }\end{array}$ \\
\hline $\begin{array}{l}\text { EGF-R positive } \\
\text { EGF-R negative } \\
\text { Totals }\end{array}$ & $\begin{array}{r}8 \\
166 \\
174\end{array}$ & $\begin{array}{r}4 \\
10 \\
14\end{array}$ & $\begin{array}{l}106 \\
555 \\
661\end{array}$ \\
\hline$\chi^{2}$ & \multicolumn{2}{|c|}{$\begin{array}{l}\text { Infiltrating lobular } v \text { Infiltrating ductal } \\
\text { carcinoma } \\
\qquad \mathrm{p}<0.0001\end{array}$} & $\begin{array}{l}\text { llary } v \text { Infiltrating ductal } \\
\text { carcinoma } \\
p=0 \cdot 180\end{array}$ \\
\hline
\end{tabular}

tyrosine kinase activity. It is relatively common in breast carcinomas (14-43\%), where it is correlated with a poor prognosis ${ }^{12}$ mainly in node negative cases. Moreover, a clearcut association between EGF-R and other immunohistochemical prognosticators of breast carcinomas has been found. ${ }^{12}$ But only cases of common infiltrating ductal carcinomas (with the worst prognosis) have been investigated. EGF-R expression has never been extensively studied in low grade tumours (tubular, mucinous, papillary and invasive cribriform carcinomas) and intermediate grade tumours (infiltrating lobular and medullary carcinomas).

\section{Methods}

Samples from 931 breast carcinomas were studied. Each tumour specimen was cut into two parts: one part was formalin fixed and paraffin wax embedded; the second part was frozen in liquid nitrogen and cut into cryostat sections. Sections from the embedded part of carcinomas were stained with haematoxylin and eosin and used to histotype cases according to the $\mathrm{WHO}^{3}$ and Page and Anderson ${ }^{4}$ indications. Pure tubular $(n=12)$, mucinous $(n=29)$, papillary $(n=30)$, invasive cribriform $(n=11)$, lobular $(n=174)$ and medullary $(n=14)$, and 661 ductal carcinomas were identified on exhaustive serial sections of specimens.

Sections obtained from frozen specimens were immunohistochemically stained. Two monoclonal antisera (Ab1 and $\mathrm{Ab} 2)$ obtained from clone 455 and 528 (Oncogene Science, Manhasset, New York, USA) were used to demonstrate EGF-R positivity. After $30 \mathrm{~min}-$ utes' incubation with normal human serum, primary antisera were diluted 1 in 10 and incubated for 1 hour at room temperature. An avidin-biotin complex (ABC) method conjugated with peroxidase was then used after incubation with biotinylated anti-mouse antibody. Each incubation was followed by a

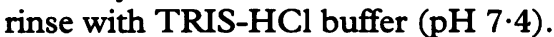

Colour was developed using filtered 3,3' diaminobenzidine $(0.5 \mathrm{mg} / \mathrm{ml})$ in TRIS$\mathrm{HCl} / \mathrm{H}_{2} \mathrm{O}_{2} 0 \cdot 7(\mathrm{v} / \mathrm{v})$.

Cases were considered EGF-R positive whatever the percentage of stained cells at the cell membrane.

Statistical analyses were performed using Fisher's exact test.

Results

A strictly membrane-linked EGF-R specific immunostaining result was found in all 
Table 2 EGF-R in low grade breast carcinomas

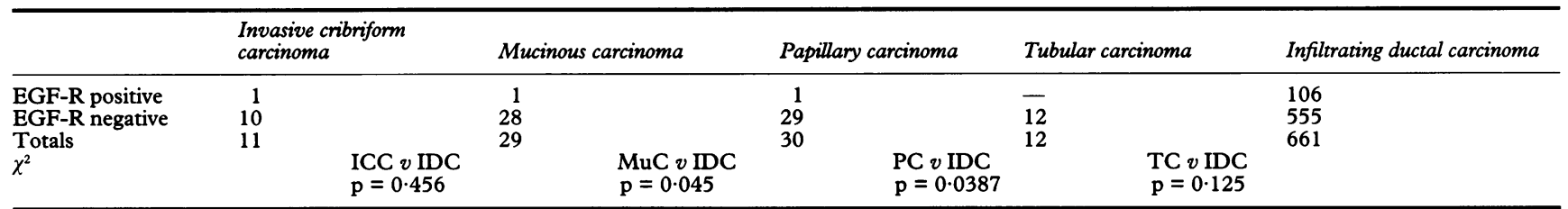

ICC = invasive cribriform carcinoma; $\mathrm{MuC}=$ mucinous carcinoma; $\mathrm{PC}=$ papillary carcinoma; $\mathrm{TC}=$ tubular carcinoma

positive cases of each histotype, without any difference between the two kinds of antisera. In some cases, however, staining in a single tumour was patchy; homogeneous immunostaining was seen in other carcinomas.

Low grade carcinomas seldom expressed EGF-R: in our study no tubular carcinoma and only one positive case each of cribriform, mucinous, and papillary carcinoma were found, compared with 106 out of 555 positive ductal carcinomas (table 2).

Differences were significant only as far as mucinous and papillary carcinomas are concerned (table 2), although the rarity of EGF$R$ positive case was fully evident in other low grade histological types.

EGF-R positivity was rare in cases of infiltrating lobular carcinoma: the difference between lobular and ductal carcinomas was highly significant (table 1). On the other hand, no difference between pure medullary and ductal carcinomas was apparent (table 1).

\section{Discussion}

The very low incidence of EGF-R positivity in the rare histological types of breast carcinoma for which prognosis is better than that of infiltrating ductal carcinoma, supports the absence of the homologous c-erbB-2 encoded membrane protein ${ }^{5}$ and nuclear p53 oncoprotein. ${ }^{6}$

The rarity of highly proliferating ${ }^{7}$ and oestrogen/progesterone receptor negative tumours ${ }^{8}$ within this group of low grade carcinomas is also well known. But there are some EGF-R positive low grade cases, just as the presence of positive $c$-erbB-2 immunostaining, at least in a few cases, has been observed. Nevertheless this last finding is controversial. ${ }^{5}$

The paradoxical behaviour of medullary carcinomas showing a relatively favourable clinical course despite high expression of the immunohistochemical markers indicative of a poor prognosis is also confirmed by EGF-R data: in fact, the incidence of EGF-R positive cases is nearly the same as that seen in infiltrating ductal carcinomas.

In cases of infiltrating lobular carcinoma, the immunohistochemical expression of EGF-R is significantly lower than that in infiltrating ductal carcinomas, although consistently present. Analogous observations have been made for other immunohistochemical predictors of prognosis. In fact, $c$-erbB-2 is either rare $^{910}$ or absent in infiltrating lobular carcinomas, ${ }^{11}$ and p53 oncoprotein is present only in occasional cases. ${ }^{6}$ Therefore, EGF-R along with $c-e r b \mathrm{~B}-2$ encoded protein and p53 oncoprotein, explains the different clinical behaviour of the histological types of breast carcinoma.

EGF-R positive low and intermediate grade carcinomas are now under clinical observation.

1 Sainsbury JRC, Farndon JR, Needham GK, Malcolm AJ, Harris AL. Epidermal-growth-factor receptor status as a predictor of early recurrence of and death from breast cancer. Lancet 1987; i:1398-402.

2 Toi M. Hamada Y, Nakamura $\mathrm{T}$, et al. Immunocytochemical and biochemical analysis of epidermal growth factor receptor expression in human breast growth factor receptor expression in human breast
cancer tissues: relationship to estrogen receptor and cancer tissues: relationship to estrogen receptor
lymphatic invasion. Int $¥$ Cancer $1989 ; 43: 220-5$.

3 World Health Organisation. International histological justification of tumours. Histological typing of breast tumours. 2nd edn. Geneva: WHO, 1982

4 Page DL, Anderson TJ, eds. Diagnostic histopathology of the breast. Churchill Livingstone: Edinburgh, 1987: 193-235.

5 Soomro S, Shousha S, Taylor P, Shepard HM, Feldmann $M$. c-erbB-2 expression in different histological types of invasive breast carcinomas. F Clin Pathol 1991;44: invasive

6 Martinazzi M, Crivelli F, Zampatti C, Martinazzi S. Relationships between p 53 expression and other prognostic factors in human breast carcinomas. An immunohistochemical study. Am 7 Clin Pathol 1993 (in press).

histochemical study. Am f Clin Pathol 1993 (in press).
Kuenen-Baumeester V, Van der Kwast ThH, Van Laarhoven HAJ, Henzen-Lagmans SC. Ki67 staining in histological subtypes of breast carcinoma and fine needle aspiration smears. $f$ Clin Pathol 1991;44:208-10.

8 Shousha S, Backaus CM, Alaghband-Zadeh J, Burn J. Alveolar variant of invasive lobular carcinoma of the breast. A tumour rich in estrogen receptors. Am $7 \mathrm{Clin}$ Pathol 1986;85:1-5.

9 Martinazzi M, Crivelli F, Zampatti C, Martinazzi S $\mathrm{C}$-erbB-2 and 53 expression in low and intermediate clinical grade breast carcinomas. Abstract 104 XIX International Congress of the International Academy of International Congress of the Interna

10 Van De Vijver M, Peterse JL, Mooi WJ, et al. Neu-protein overexpression in breast cancer. Association with comedo-type ductal carcinoma in situ and limited prog nostic value in stage II breast cancer. $N$ Engl $\mathcal{F} \mathrm{Med}$ 1988;319: 1239-45.

11 Gusterson BA, Machin LG, Gullick WJ, et al. Immunohistochemical distribution of c-erbB-2 in infiltrating and in situ breast cancer. Int $\mathcal{F}$ Cancer 1988;42 $842-5$. 